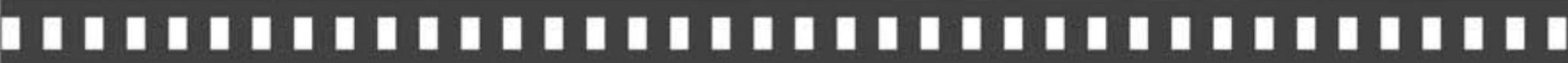

\author{
Imágenes desquiciadas. Una conversación \\ sobre (post)fotografía, tiempo y memoria \\ con Joan Fontcuberta.

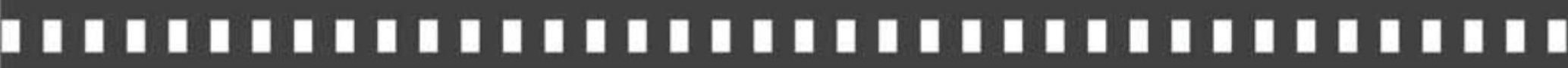

\author{
Joan Fontcuberta \\ Mónica Alonso Riveiro
}

Artigo recebido em: 30/11/2020

Artigo aprovado em: 18/12/2020 


\title{
Imágenes desquiciadas. Una conversación sobre (post)fotografía, tiempo y memoria con Joan Fontcuberta
}

\author{
Images Out of Joint. A Conversation about (Post)photography, \\ Time and Memory with Joan Fontcuberta.
}

\author{
Joan Fontcuberta* \\ Mónica Alonso Riveiro**
}

Resumen: A lo largo de esta conversación con uno de los principales teóricos de la postfotografía, Joan Fontcuberta, abordaremos la transmutación de los valores asociados a lo fotográfico que este concepto describe y los nuevos órdenes de lo visible que la era postfotográfica ha impuesto. Pensaremos, también, en la memoria y el olvido, el tiempo o el azar, y en el poder de las imágenes para dar forma al mundo y trazar nuevos puentes y solidaridades hacia el pasado.

Palabras clave: Postfotografía. Joan Fontcuberta. Visibilidad. Representación.

\begin{abstract}
Throughout this conversation with one of the main post-photography theorists, Joan Fontcuberta, we will discuss transmutation of photographic values that this post-photography era describes and the new visual order it imposed. We will also think of memory and oblivion, time and fate and about the power of images to give form to the world and trace new solidarities with the past.
\end{abstract}

Keywords: Post-photography. Joan Fontcuberta. Visibility. Representation.

${ }^{*}$ Artista, ensayista y docente.

** Investigadora postdoctoral en la Universidad Nacional de Educación a Distancia (UNEtD). Dpto. de Historia del Arte. 
"La imagen no es de quien la hace sino de quien la utiliza" Jean Luc Godard.

En su ensayo La furia de las imágenes. Notas sobre la postfotografía, Joan Fontcuberta traza el retrato de una época caracterizada por la producción masiva de imágenes y por el incremento de su circulación y disponibilidad en medios digitales. Sin embargo, nunca nos permite considerar esta nueva situación desde la óptica de una mera mutación técnica sino que apunta sin ambages a que estamos ante una transmutación real de valores asociados a lo fotográfico y ante el "desmantelamiento de la visualidad que la fotografía había implantado de forma hegemónica durante un siglo y medio" (FONTCUBERTA, 2016, p. 28).

A la nueva visualidad que viene a sustituir a la precedente vamos a dedicar este estudio, para pensar precisamente con el artista, crítico y docente Joan Fontcuberta ante qué nuevos ordenes -del tiempo, de lo visible, de lo real- nos encontramos. Se transitará, junto a uno de los principales teóricos del concepto de postfotografía, a través de cuestiones que siempre han sido centrales en su trabajo y que resuenan en nuestros intereses, interrogando los mecanismos de reapropiación y producción de sentido y pensando en el poder de las imágenes para dar forma al mundo o para trazar nuevos puentes y solidaridades hacia el pasado. Pensaremos, también, en la memoria y el olvido, el tiempo o el azar. La forma dialogada de este texto, de inspiración socrática, respeta y refleja el método de trabajo de esta indagación conjunta, al tiempo que reivindica el potencial epistémico de la conversación ${ }^{1}$.

1 La conversación que sigue se inició, con ayuda de medios digitales, en algún 


\section{Memoria e imaginación}

Mónica Alonso Riveiro. Me gustaría comenzar recuperando unas palabras tuyas referidas a tu último trabajo, Mictlán (2020), en que salvas de archivos mexicanos fotografías enfermas, deterioradas por la humedad, el moho o los microorganismos. Imágenes, en tus palabras, reducidas a huellas fantasmales en las que el recuerdo desfallece y, quebrantado su vínculo con la realidad, su condición de documento se desvanece. Refiriéndote a ellas afirmas que "la posmemoria no se conecta con los hechos mediante una mera constancia de datos sino a través de una implicación creativa, da voz a los marginados y produce nuevas empatías con el pasado" (FONTCUBERTA, 2020).

Esta frase llamó mi atención hasta decidirme a abrir con ella esta conversación porque recurres a un término, el de posmemoria, que nos ha hecho pensar mucho en los últimos tiempos, pero al que, hasta el momento, no te habías referido demasiado en sus reflexiones. Me gusta mucho lo esas palabras permiten intuir de tu noción de posmemoria ya que, contrariamente al uso determinista que algunos teóricos dan a este concepto -como si fuese irremediable heredar ciertos recuerdos traumáticos en una cadena casi siempre familiar- parecen sugerir que todos podemos heredar o, recuperando tu terminología, adoptar imágenes, recuerdos y memorias ajenas a lo largo del tiempo. Abres así la posibilidad de una posmemoria otra, más abierta, que permite reactivar memorias y generar nuevas empatías y solidaridades más allá de lo familiar o lo traumático. Creo

lugar, tierra de nadie, entre Tours y Granollers el 18 de noviembre de 2020 y ha seguido creciendo con la ayuda de Joan. 
que se trata también de una posmemoria más creativa, que permite enfrentarse a los restos no inventariándolos sino de esa manera que para Benjamin era la única posible: empleándolos² ${ }^{2}$ BENJAMIN, 2013). ¿Te sientes reflejado en esa concepción? ¿Podrías profundizar en cómo te relacionas con esa noción de posmemoria?

Joan Fontcuberta. Es una pregunta que contiene ya la respuesta. Para empezar, de todas maneras, siempre que trato cuestiones así quiero dejar claro que yo no hablo desde la perspectiva del académico ni del investigador ni del teórico. Yo soy un creador, me autodenomino un artista curioso y la curiosidad me impulsa a reflexionar sobre las materias que me interesan. Siempre me considero más no un experto sino un diletante. En estos ámbitos lo que hago es merodear por aquellas parcelas de la sensibilidad que quedan cerca de mi trabajo, yo no hablo de cosas que no tengan alguna relación cercana con mis propias preocupaciones como creador. El tema de la posmemoria estaba flotando ahí, me interesaba, he leído el libro de $\mathrm{Hirsch}^{3}$, lo compré hace muchos años y quedó en un rincón, y de repente lo redescubrí en uno de esos momentos que uno hace como una arqueología de la propia biblioteca. De repente apareció y me interesó porque empezaba a sonar en diferentes ámbitos.

Hace un par de años me invitaron a escribir un texto sobre un fotógrafo colombiano, Luis Carlos Tovar, que vivió la experiencia traumática de la violencia en su país. Su padre fue secuestrado por la guerrilla de las FARC, estuvo varios meses recluido en la selva,

2 Paráfrasis de Benjamin que, en el texto original dirá "No voy a sustraer nada valioso, ni apropiarme de ninguna formulación ingeniosa. Pero sí los harapos y los desechos: no pretendo inventariarlos, sino hacerles justicia de la única manera posible, esto es, empleándolos" (BENJAMIN, 2013, p. 739). [NI a, 8].

3 Se refiere a (HIRSCH, 2015). 
finalmente se pagó un rescate y fue liberado, pero los raptores no quedaron satisfechos y siguieron amenazando a la familia, que huyó a Bogotá. Ellos vivían en una región amazónica al sur del país, en ese viaje el avión se estrelló... un drama tras otro. Cuando eso sucedió el fotógrafo era un bebé que estaba en los brazos de su padre en el momento en que se lo llevaron. Al final el padre regresa, se reintegra en la familia, pero la experiencia ha sido tan dolorosa, tan intensa, que permanece como un tabú. De eso no se habla en la familia, hay un silencio -tú has hablado del silencio de los republicanos en la posguerra-, un silencio espeso que impide la normalidad. Un buen día, cuando ya es adulto, Luis Carlos es fotógrafo y pide visionar los materiales y documentos guardados en una caja: las cartas que habían enviado los secuestradores, la polaroid que habían tomado a su padre para demostrar que seguía vivo. A Luis Carlos le guía de algún modo el intento de hacer un ajuste de cuentas con esa memoria tan herida que imposibilitaba la normalidad de las relaciones familiares y sociales. Eso tiene lugar al mismo tiempo que en Colombia se produce un acercamiento entre el gobierno y las FARC para culminar unos acuerdos de paz; ese proceso personal de Luis Carlos se proyecta sobre un proceso social y político en el país, con lo cual su gesto tiene casi un carácter simbólico, no solo individual, que ejemplifica la voluntad de pasar página que se experimenta en Colombia.

Es a partir de ahí que me empieza a interesar más esa idea de la postmemoria. De este proyecto ha salido un libro, llamado Jardín de mi padre (TOVAR, 2020) ya que la única ocupación del padre, cuando regresa, es dedicarse a su jardín. Es lo único que le permite evadirse de su memoria herida. El fotógrafo entonces lo que hace 
252 Imágenes desquiciadas. Una conversación sobre (post)fotografía, tiempo y memoria con...

es mezclar estos documentos con las plantas, las flores que hay en el jardín, pero éstas aparecen impresas en unas cianotipias al estilo de Anna Atkins o de Henry Fox Talbot en el siglo XIX. Para mí esa práctica ilustra de una manera ejemplar la idea de posmemoria: no se trata de hacer una arqueología de lo que pasó, ni recuperar una línea biográfica o cronológica de los hechos. Sino, al revés, insuflar a esos materiales una nueva vida que permita el olvido o el perdón, que son dos términos que van parejos. Hace poco escuché una entrevista a William Kentridge, cuya obra evoca la costosa superación de la Sudáfrica del apartheid, y se expresaba en términos parecidos.

Figura 1 - Luis Carlos Tovar, Dos imágenes de Jardín de mi padre 4.

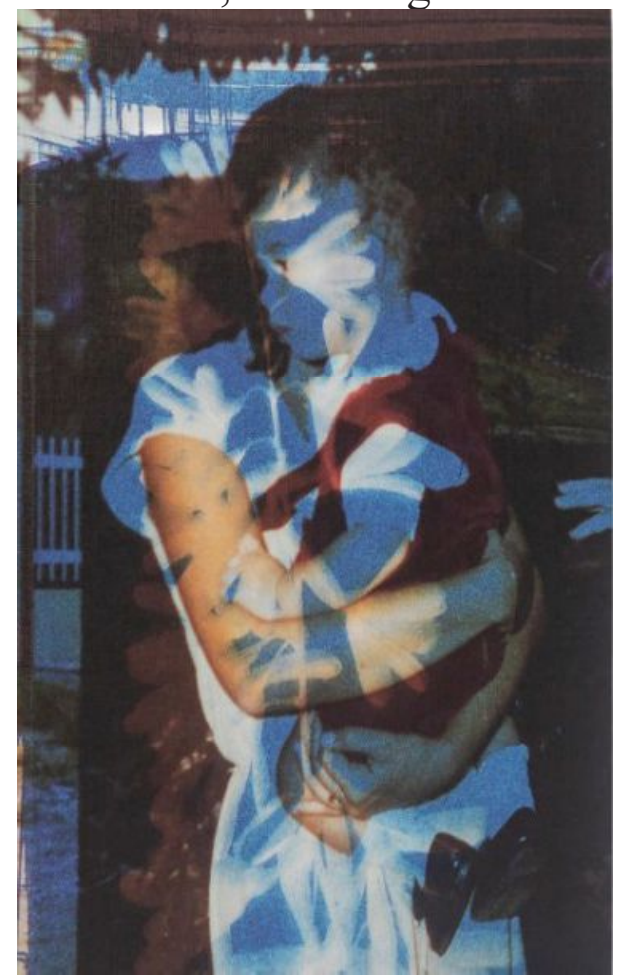

4 Consultado en: http://luiscarlostovar.com/ 


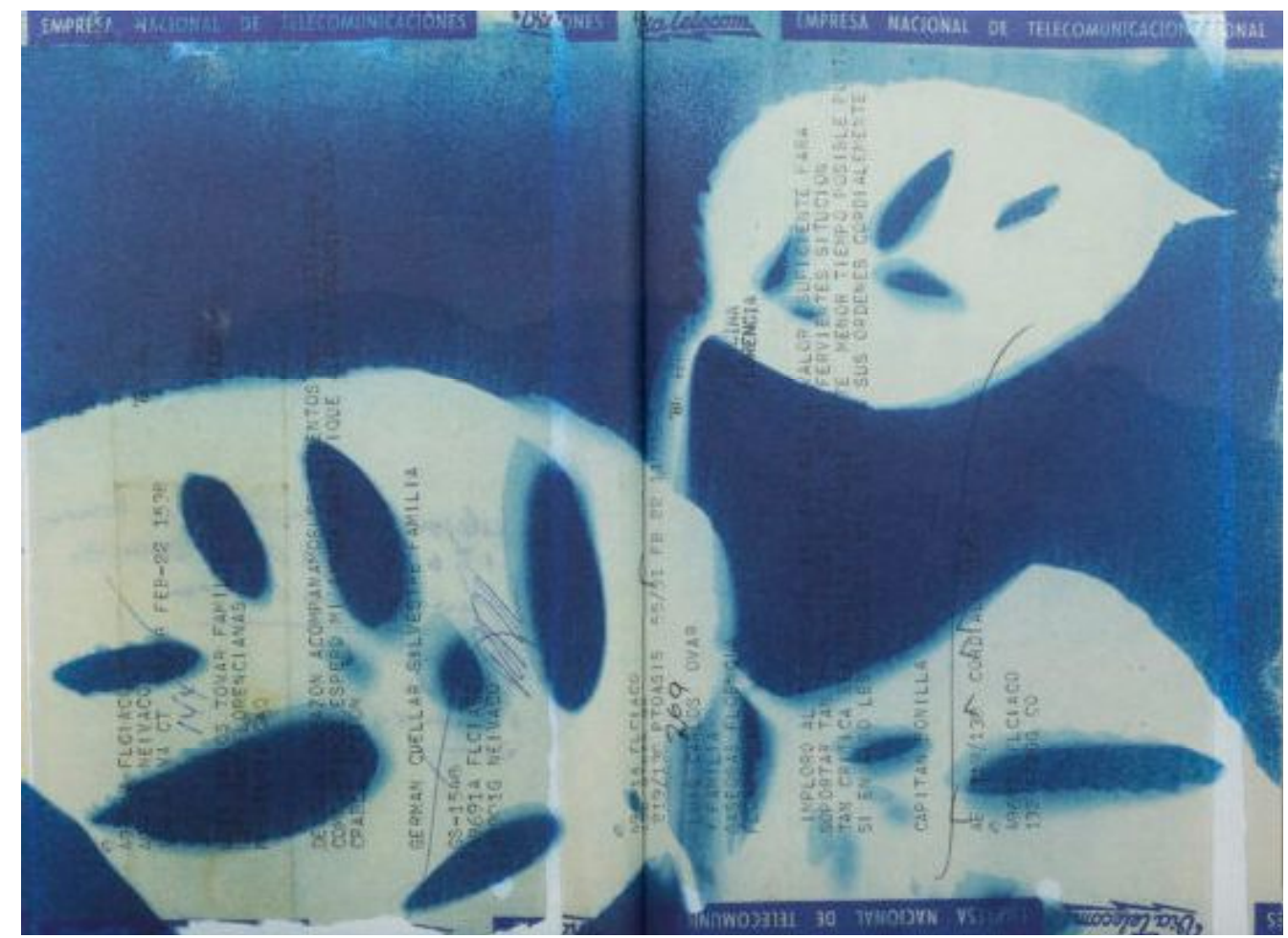

Fuente: Tovar (2020).

Hay un tema que a mí me parece muy interesante en la postfotografía que es que da más importancia al olvido que a la memoria. La fotografía se ha entendido siempre como un dispositivo de memoria, un dispositivo de verdad, un dispositivo de identidad, de archivo, etc. pero, sobre todo, de memoria. Cuando aparece el daguerrotipo, lo que hace es suplir las carencias de la capacidad mnemotécnica que tenemos. La idea de documento significa la voluntad de preservación de una información frente a las limitaciones de la capacidad de almacenaje de nuestro cerebro. Esa memoria, como la verdad, ha constituido el andamiaje ideológico de la fotografía, que ha evolucionado en el XIX y hasta finales del XX como refuerzo de nuestras propias facultades sensoriales. Hoy nos encontramos con que existe un movimiento pendular que propone la necesidad del olvido y que se manifiesta en muchas facetas de 
la vida en comunidad. Por ejemplo, ha surgido una ley, The right to be forgotten, que reclama la opción de ser olvidado, que aspira a protegernos de demasiada memoria, un exceso que a veces llega a atemorizarnos, esa memoria a lo Funes el memorioso de Borges, que se vuelve contra nosotros. Para avanzar como humanos a veces debemos soltar lastre y olvidar; olvidar se convierte entonces casi en un gesto de supervivencia, supervivencia personal pero también social. Pero ¿cómo olvidar cuando nos hemos dotado de unos dispositivos de memoria tan potentes como la fotografía, los bancos de datos, las memorias digitales...? Hay, insisto, una tendencia hacia el derecho al olvido, que para mí tiene que ver con la práctica cada vez más intensa de la posmemoria en artistas contemporáneos, pero también con la postfotografía, que no niega la posibilidad de la memoria pero que la relega a una opción entre muchas posibles: el pastel ahora tiene que repartirse entre muchos otros factores. Podemos seguir usando la fotografía como un carnet de notas, claro, pero no es lo único. Por ejemplo, ahora, durante la pandemia, los restaurantes ya no te facilitan un menú, sino que tienes que fotografiar la lista de platos disponibles escritos en una pizarra o visualizar un código QR mediante el cual accedemos al menú. O sea, lo que nos están pidiendo es que usemos la cámara para memorizar unos datos, pero una vez satisfecha esa función, la imagen deja de tener utilidad y generalmente se borra, no hay una voluntad de preservarla. En décadas anteriores la fotografía se reservaba al registro de situaciones que considerábamos de relevancia, solemnes. La fotografía representaba una inversión en coste y energía que se justificaba para enaltecer un determinado acto social. La presencia de la cámara daba una envergadura a lo que estaba sucediendo. Incluso Benjamin dijo 
que la aparición de la fotografía convertía la historia en la crónica de aquello que era fotografiable. Sin cámaras, sin imágenes, no había hechos, por lo tanto, no había historia. En los usos sociales de la fotografía permanece la voluntad de registro, de usarla como carnet de notas, pero sin esa exigencia de perdurabilidad. Antes la memoria era una obligación, ahora es una opción.

MAR. Respecto a la memoria y a las posibilidades de traer imágenes al presente para imaginar con ellas, para construir a partir de ellas nuevas memorias, me pregunto -pensando también en tu trabajo- si devolver la materialidad a la imagen no se convierte en una necesidad previa a ese quehacer. Es decir, ¿re-materializar las imágenes sería un paso previo para activarlas hoy? ¿acaso no hay sólo que dar (prescribir) sentido, sino que dar cuerpo, materia? Rematerializar la imagen, convertirla en un objeto físico, interrumpiendo el flujo de las imágenes y extrayendo determinadas imágenes del mismo ¿no es una oportunidad para cuestionar ese flujo y para poder, también, pararnos a pensar?

JF. Yo contradeciría la idea de que hay un impulso de la imagen a re-materializarse. No lo veo así, puede que sea una cuestión de perspectiva. Entiendo que la fotografía convencional ha sido siempre objeto, poseía una palpabilidad. La imagen contenía una información, pero la superficie de inscripción de esa información era el papel, o el cristal, algo que se tocaba, que ocupaba espacio y tenía las cualidades de la materia: la podíamos acariciar, la podíamos rasgar, la podíamos quemar... en cambio, la superficie de inscripción de la fotografía digital o de la postfotografía es la pantalla. Y la pantalla es algo que requiere unos elementos objetuales, pero que no pertenecen a la sustancia de la imagen misma, la sustancia que la 
256 Imágenes desquiciadas. Una conversación sobre (post)fotografía, tiempo y memoria con...

hace única, y en el fondo esos elementos son intercambiables. Una de las cualidades de la postfotografía es la ubicuidad, es decir, que la imagen ha dejado de ser algo único y físico, aunque suela necesitar un decodificador para hacerse visible. Esencialmente la imagen es ahora una combinación de unos y ceros, es pura información. La materialidad entonces se desplaza de la imagen al dispositivo lector. Pero es como si el alma haya abandonado el cuerpo. ¿Qué pasa cuando no tenemos cuerpo? Que nos convertimos en espectro, en fantasma, y esa dimensión espectral actual de la postfotografía modifica las maneras de relacionarnos con las imágenes.

Figura 2 - El párroco de la iglesia Robbiano en Giussano oficia misa ante las fotos de sus feligreses ${ }^{5}$.

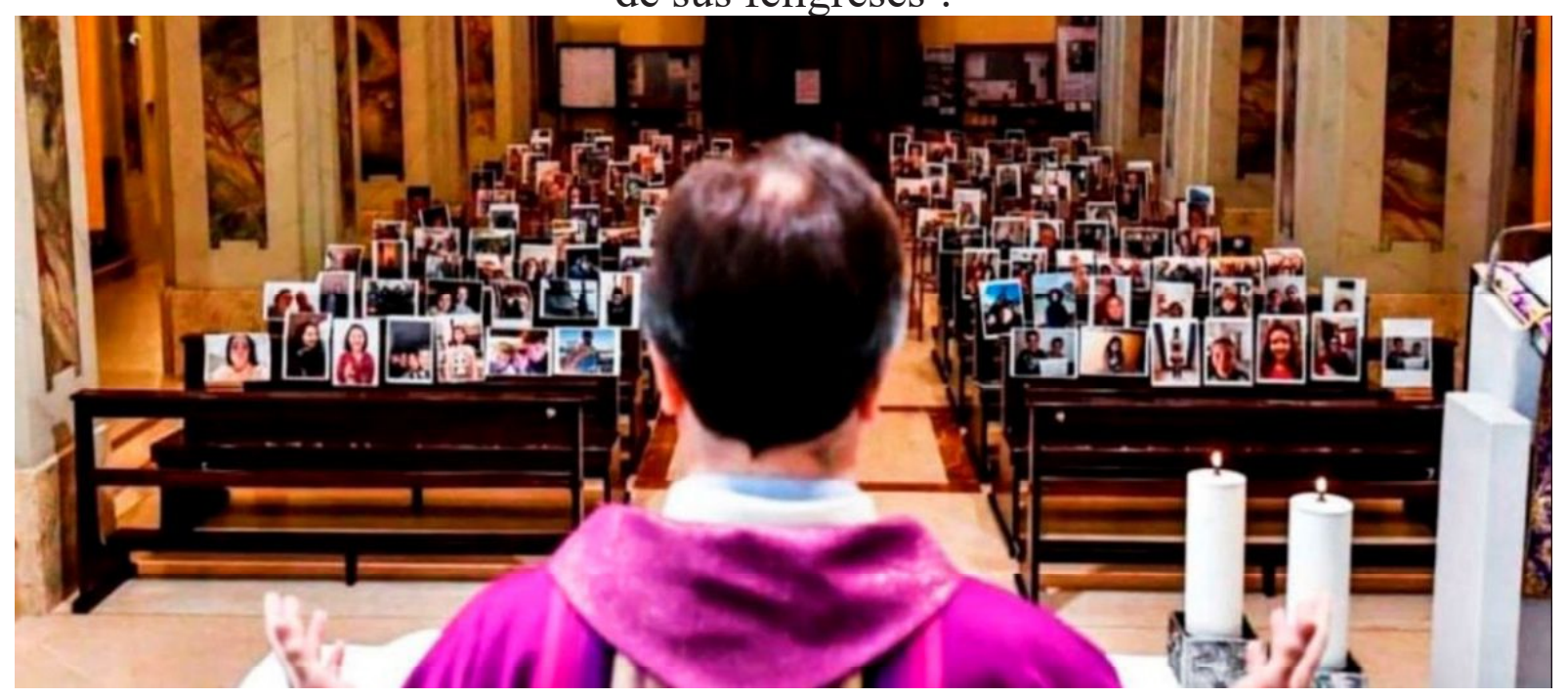

Fuente: Coronavirus ... (2020).

Yo sostengo que la fotografía muchas veces reemplaza mágicamente a la realidad. Por ejemplo, cuando hay protestas contra el rey y se queman sus retratos, lo que queremos no es quemar papel, es trasladar esa acción punitiva a la figura institucional y política

5 Consultado en: https://www.clarin.com/viste/coronavirus-italia-pueden-iriglesia-sacerdote-da-misa-selfies-feligreses_0_sXyloLEbL.html 
que nos disgusta representada sobre ese papel. O cuando, hace poco, en una localidad al norte de Milán que se llama Robbiano, el párroco celebraba los servicios religiosos con la iglesia vacía debido al confinamiento por la Covid-19, pero pedía a los feligreses que enviasen una foto suya que era colocada en los bancos (fig. 2). Entonces el párroco oficiaba la misa y se entendía que la presencia de los fieles estaba siendo reemplazada simbólicamente por fotos interpuestas. Pero lo interesante es que a nivel de precepto cristiano eso ya validaba la asistencia a misa, el mandamiento de santificar las fiestas se cumplía, no era pecado quedarse en casa si la imagen asistía a la iglesia por nosotros. Y es de suponer que Dios bendecía tal delegación. Ese proceso de transubstanciación se pierde, tú no puedes enviar una imagen digital que te represente, necesitas corporeizarla en algo.

MAR. Pero, a ese párroco, ¿le hubiera bastado una imagen digital? ¿No es más sencillo considerar que hay una presencia si esta se materializa en un objeto, en una foto impresa sobre papel?

JF. Fíjate, la imagen digital necesita un lector. ¿Qué es la imagen digital? Un archivo, un código que descifrado por un determinado lector se hace visible, pero por ella misma es algo absolutamente ininteligible, no tiene materialidad, necesita que algo le preste esa materialidad para que podamos actuar con ella. En cambio, la fotografía tradicional, desde el daguerrotipo hasta las fotos que hasta hace unas décadas todavía llevábamos a los establecimientos de revelado rápido, eran objetos, recortes de papel. Lo interesante es que en la medida en que las llevábamos en el bolsillo, en la cartera, su peso, su volumen, su presencia, hacía que les otorgásemos ese valor, parecido al que tienen las estatuillas en 
258 Imágenes desquiciadas. Una conversación sobre (post)fotografía, tiempo y memoria con...

los rituales vudú. Hay una película que se llama Los Espectros, que documenta una práctica realizada en el BAU consistente en recoger las reacciones de personas ante seres queridos que rasgan o destrozan sus fotos. Es la demostración antropológica de que nuestra fotografía es mucho más que un trozo de papel, que el daño que puedas infringir a mi fotografía en el fondo es un daño que me infringes a mí, hay una suerte de correlación, de sincronicidad 6 .

MAR. Retomando estas disfunciones de lo que nos ha pasado a nosotros (y a nuestras imágenes) durante la pandemia recuerdo una imagen que me impresionó mucho. Provenía de un reportaje que leí en Liberation. En él, un hombre narraba que ante su imposibilidad de visitar a su padre muerto su hermano, que estaba junto a su padre, le había enviado una foto de su cadáver. $\mathrm{Su}$ testimonio finalizaba con la afirmación "Él lo ha visto, yo no tengo más que imágenes" (PILORGET-REZZOUK, 2020, p. 15), instalando una diferencia esencial entre ver un cuerpo y ver la imagen del mismo, su representación. Creo que es un buen ejemplo para, con ayuda del lenguaje cotidiano, permite pensar qué dimensiones de la experiencia asimilamos con el acto de ver o cómo éste se identifica con estar frente a algo, con experimentar su presencia físicamente. Me parece que este ejemplo es un buen lugar desde el que pensar la distancia entre representación y presencia.

Por otra parte, leyendo el reportaje imaginaba la existencia de este tipo de imágenes circulando como actos de comunicación, $6 \mathrm{El}$ proyecto recoge un trabajo de campo realizado por Jorge Luis Marzo en el Centro Universitario de Diseño BAU de Barcelona que se interroga por qué sucede cuando alguien rompe tu foto. Un resumen de los más de 700 registros videográficos grabados en secreto por estudiantes universitarios.

Puede verse en: https://www.cccb.org/es/multimedia/videos/por-que-merompes $/ 228412$ 
destinados a comunicar la muerte. Me pregunto -y te pregunto- si en estos momentos en que la hipervisibilidad y el uso de medios digitales se han convertido más en una obligación que en una opción no veremos regresar antiguas imágenes, como estas fotos de muertos hechas para permitir el duelo, circulando en nuevos canales. ¿Podemos pensar que, como decía Freud (1982), cuando la muerte no se deja ya negar regresan, también a las imágenes, usos antropológicos antiguos?

JF. Yo he realizado en Barcelona un proyecto que se titula "Miradas desde el confinamiento" " que consistía en solicitar a la gente imágenes de lo que hacía durante la reclusión: sus momentos más pletóricos y sus momentos de decaimiento. Hemos recibido 64000 fotos que componen una especie de mosaico sociológico fantástico de qué hace la gente cuando se tiene que quedar en casa. No he hecho un análisis sociológico, pero lanzando una mirada rápida nos damos cuenta de que hay muchas fotos de cocina, la gente se pone a hacer pan o a hacer paella... esta postfotografía es fundamentalmente un instrumento de comunicación, de lenguaje, de intercambio, de compartir. Compartir fotos significa compartir vivencias y compartir vivencias significa construir comunidad. Hay una frase que a mí me gusta mucho de Virilio que dice "inventar el barco significó inventar el naufragio, inventar la locomotora significó inventar el descarrilamiento [...]"8 $\mathrm{El}$ accidente está latente en cada nueva tecnología. Y se podría decir inventar la fotografía, significaba compartirla. Hoy las fotos las hacemos para compartir

7 El proyecto, realizado con Òmnium Cultural, puede consultarse en: https:// miradesdesdelconfinament.cat/es

8 La idea de que "inventar un objeto técnico, es inaugurar un accidente específico" permea toda la obra de Virilio. Ver, por ejemplo: (VIRILIO, 1997). 
260 Imágenes desquiciadas. Una conversación sobre (post)fotografía, tiempo y memoria con...

determinadas situaciones, determinados momentos, eso puede ser “iqué bien me ha quedado la paella!” o puede ser "esa es la lápida de tu abuelo que ha muerto mientras no podíamos ir a su entierro". Son formas de escapar de la reclusión; una de las peculiaridades de la fotografía postfotográfica es su capacidad de penetración, de circulación, podemos enviarlas y recibirlas inmediatamente, sin ningún coste y a donde sea; es como expandir globalmente unos tentáculos con sensores. Y eso implica la combinación de la imagen fotográfica del siglo XIX con toda una serie de posibilidades y plataformas tecnológicas del siglo XXI que le dan a la fotografía unas capacidades de comunicación y de peso en nuestro quehacer vital mucho más potentes.

Figura 3 - Joan Fontcuberta. Mosaico y detalle de las imágenes que componen Mirar desde el confinamiento.
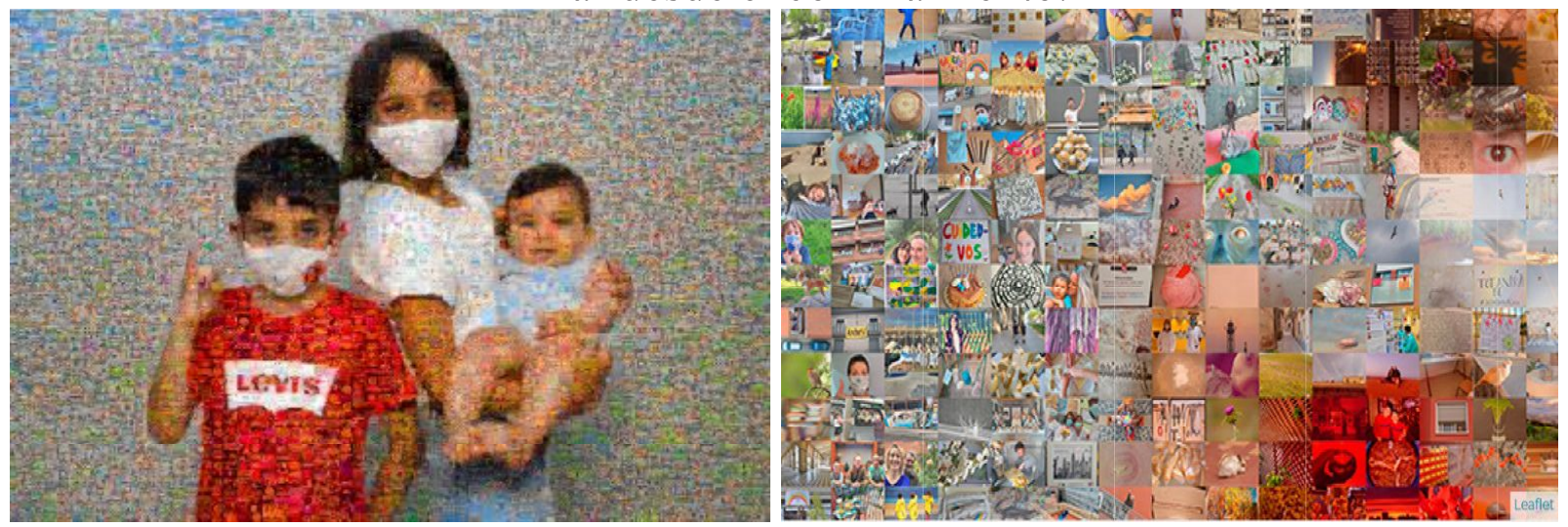

Fuente: Cortesía del autor.

\section{Imagen y tiempo}

MAR. Otro tema central en todo tu trabajo y que me gustaría pensar contigo es la relación entre la fotografía y el tiempo. Quisiera hacerlo a partir de otra cita tuya, de nuevo proveniente de 
La furia de las imágenes: "Si la fotografía nos habla del pasado, la postfotografía nos habla del presente, porque lo que hace justamente es mantenernos en un presente en suspensión, eternizado. Vivimos en un presente continuo que es la tierra de nadie entre el horizonte de las experiencias y de las expectativas" (FONTCUBERTA, 2016, p. 114). En este texto retomas la terminología de Koselleck (1993), pero también de Hartog (2003) cuando usa un marco similar para desarrollar sus ideas en torno al presentismo. ¿consideras que la postfotografía sería un elemento más de este régimen de temporalidad presentista defendido por Hartog? ¿coincides con sus análisis?

Y, dándole aún otra vuelta, ¿no podríamos hablar, más allá del presentismo, de un nuevo orden del tiempo trastornado? Pienso, por ejemplo, en la capacidad de la postfotografía de convertir cada acontecimiento en un pasado inmediato que generaría lo que algunos autores denominan como una "nostalgia del presente" (LACHANCE, 2013). Pienso también en ciertas teorías, aplicadas sobre todo a los adolescentes, que nos hablan de un uso de la fotografía como una herramienta destinada a dominar el tiempo o, al menos, a crear la sensación de que puede ser dominado. ¿Cómo te sitúas en este terreno? ¿qué nos dice la postfotografía sobre el orden del tiempo?

JF. La fotografía nació para referirse al pasado y en general todo el pensamiento y la literatura teórica ha ahondado en la idea del ça-a-été. La fotografía implica mirar hacia atrás, mirar por el retrovisor. En cambio, la postfotografía hace prevalecer el presente, porque se mueve en un régimen de historicidad distinto que viene dado por la hipermodernidad; una hipermodernidad caracterizada por la velocidad, la aceleración, la inmediatez. En la historia de la fotografía, si reflexionamos sobre el papel que juega la imagen 
fotográfica en el orden del conocimiento, en el orden de la transmisión de saberes, advertimos una concatenación de etapas: tenemos un suceso, tenemos la llegada de la cámara del reportero, tenemos la difusión de esta imagen como noticia, y tenemos su recepción por parte del público. Tenemos cuatro fases, en cambio hoy esas fases se funden, se comprimen en una sola; hoy todo acontecimiento es un acontecimiento-imagen; la imagen hace al acontecimiento. En el momento en que un suceso se está produciendo, una imagen de ese acontecimiento ya está llegando al público. Todo es en directo, todo es life, todo es en tiempo real. Y es verdad que, como has mencionado, eso tiene que ver con una especie de sensibilidad que podemos considerar propia de una generación de jóvenes nativos digitales que a los diez, a los doce años, ya tienen un Smartphone para comunicarse y están habituados a esta mensajería instantánea, al hecho de que todo es ahora. Eso da una hegemonía al presente, siguiendo las teorías de Hartog, que nos dice que en el fondo no nos interesa el pasado porque nos explica el presente y nos previene para el futuro, sino que es desde el presente que inventamos el pasado y hacemos una suerte de proyección hacia el futuro. Sería el presente la única realidad que está a nuestro alcance y desde la cual proyectamos todo lo demás. Eso, evidentemente, tiene que ver de nuevo con la memoria y el olvido, con la verdad y la ficción.

MAR. Por otra parte -y es una pregunta para la que no tengo ni tan siquiera hipótesis- en este orden del tiempo, ¿qué pasa con el futuro? Parece claro que podemos subordinar el pasado al presente; inventándolo desde este presente que se nos aparece cómo el único lugar real; e incluso parece razonable, pensando en términos postfotográficos, que podamos sentirnos irresponsables de 
un pasado que registramos inmediatamente, pero, ¿hemos olvidado el futuro? Las teorías de Hartog por las cuales existiría un principio de de responsabilidad o previsión derivado de considerar el futuro una suerte de prolongación del presente, ¿pueden conectarse de algún modo con la era de la postfotografía? ¿podemos pensar nuestra relación con el futuro en términos de responsabilidad o previsión? ¿podemos tomar precauciones con las imágenes?

JF. Esa es una cuestión de calado filosófico para la que me gustaría tener respuesta. Pero hay un dato que interviene y es la cada vez más presente influencia de la física cuántica, de la teoría de los mundos posibles, de los multiversos. La física cuántica supone un golpe durísimo al mecanicismo newtoniano que configura el determinismo: el hecho de que el mundo es un mecanismo de relojería de manera que si conocemos la posición, la energía, etc. de cada pieza podemos anticipar los movimientos de todo el sistema. De repente, esa teoría se ve, no negada pero complementada por otra que nos dice que, en determinados niveles de observación, con puntos de partida iguales, los resultados no son necesariamente los mismos. Lo cual nos lleva a una cuestión que a mí me seduce mucho que es el cuestionamiento del principio de realidad. El principio de realidad dice que las cosas existen más allá de que yo las mire. Yo te estoy viendo a ti, pero en el momento en que yo apague el ordenador y no te vea, tú sigues existiendo, tú sigues viviendo (quién sabe). En cambio, la física cuántica nos dice que no, que la realidad depende de la posición del espectador. Por lo tanto, todo eso del futuro es embarcarnos en una ciencia ficción especulativa, apasionante, a nivel de propuesta intelectual, fantástica, pero a nivel práctico no sé cómo resolverlo. En todo caso, cuando tomo un avión y mi vida está 
en manos de las leyes de la aerodinámica me gusta pensar que todo funcionará de acuerdo con Newton.

MAR. Quisiera regresar de ese futuro incierto hacia unas cuestiones de orden más general sobre la postfotografía. Algo que me interesa mucho es la claridad con la que expones que, pese a la importancia de las nuevas tecnologías en el desarrollo de ese concepto, no estamos ante una simple mutación técnica sino citándote de nuevo- ante una transmutación real de valores asociados a lo fotográfico y ante el "desmantelamiento de la visualidad que la fotografía había implantado de forma hegemónica durante un siglo y medio" (FONTCUBERTA, 2016, p. 28). Quisiera retomar esta cita porque me parece, a menudo, al hablar de postfotografía, y de otros "post", tendemos a focalizarnos en qué es lo que hemos dejado atrás pero no tanto en lo que tenemos ante nosotros, en lo que está pasando, de lo que esos nuevos "post" nos hablan. Prolongando tus palabras, te refieres, incluso, al "fin de la tiranía del viejo orden visual" (FONTCUBERTA, 2016, p. 28). Tras la caída de ese orden, ¿ante qué orden (otro) nos encontramos? Y, en él, ¿qué nuevos regímenes de visibilidad son posibles?

Pienso, por ejemplo, en la posibilidad, a la que te refieres en el texto, que han alcanzado ciertos colectivos subalternizados -subalternizados también en el orden de lo visible- como las mujeres, los niños o ciertas minorías, de crear y difundir sus propias imágenes, ¿podemos hablar de una autoafirmación? ¿qué nuevos ordenes de lo visible tenemos hoy y cómo se relacionan éstos con nuevos órdenes de lo real?

JF. Es un tema muy amplio. Comencemos en 1989, para mí es un hito ya que coinciden varias cosas decisivas: en primer 
lugar, cae el muro de Berlín, lo que significa el fin de un cierto orden político, de un cierto equilibrio de poderes en el mundo que conduce a una nueva era. Ese mismo año un señor que se llama Fukuyama habla del fin de la historia ${ }^{9}$ y ese mismo año aparece photoshop. Algo que para mí es otro agente revolucionario, otra caída de un meteorito de la que no nos dimos cuenta en su momento pero que también terminaba con un cierto orden visual ¿Cuál era? El del pacto mimético. La fotografía, siguiendo una tradición del arte, había mantenido el pacto mimético como programa doctrinal fundamental. A partir de ese momento se hace obvio a nivel social que la fotografía no necesariamente va a cumplir ese mandato de representación realista y empieza a actuar bajo otros protocolos Está claro que podemos señalar rupturas anteriores de ese pacto: las vanguardias, los fotomontajes desde el XIX, todo ello existía, pero no dejaban de ser acciones muy limitadas al ámbito artístico y no formaban parte de una cultura visual generalizada; hoy, en cambio gracias a la aparición del Photoshop, de la tecnología digital, etc. cualquier niño sabe que poniendo unos filtros de Instagram puede modificar su rostro, o el paisaje, o puede hacer que una escena luzca como una tarjeta postal cuando en realidad es un día gris y triste. Existe la conciencia de que la imagen es una información absolutamente maleable, no un espejo, no un reflejo mecánico sobre el que no podemos hacer nada que no sea venerar la verdad implícita en su naturaleza.

Todo eso ha ido evolucionando: han aparecido internet, las redes sociales, las cámaras de vigilancia, las cámaras satelitales, los programas de reconocimiento facial... se ha ido dando cada vez más

9 El primer texto de Fukuyama que recoge esta idea "The end of history?", se publicó en The National Interest el verano de 1989. 
266 Imágenes desquiciadas. Una conversación sobre (post)fotografía, tiempo y memoria con...

una serie de circunstancias en las que el ojo ha ido siendo sustituido por una inteligencia artificial, por una tecnología exponencialmente avanzada respecto a las primeras incursiones de la tecnología digital, hasta el momento en que la posición central de las imágenes mecánicas de hoy ya no es el binomio cámara y ojo sino algoritmo e inteligencia artificial. Todo ello configura un panorama de uso de las imágenes completamente distinto. Nos coloca en un paisaje en el que, tal vez, con una cierta nostalgia, debemos preguntarnos qué se ha hecho de las imágenes todavía humanas. Cada vez las imágenes se convierten más en el lenguaje de las máquinas, incluso operan sin nuestro permiso, sin nuestra aquiescencia, por eso yo hablaba de imágenes furiosas, imágenes que salen del quicio, se desquician, y llegan a operar casi como formas autónomas. Ese estadio postfotográfico significa un cambio de paradigma cultural con relación a la imagen y teniendo en cuenta que imagen quiere decir poder, que controlar la imagen significa controlar un determinado poder, -como suele decirse, una causa sin imágenes no es una causa ignorada, es una causa perdida- $y$ es a través de las imágenes como se puede formatear una conciencia, individual o colectiva. Por lo tanto, la batalla de las imágenes tiene hoy un impacto crucial en la economía, en la política, en todo. El control de la imagen -podríamos decir también el control del relato, pero para mí ese relato se sustenta casi siempre en imágenes- es vital en cualquier tipo de confrontación ideológica. Cada vez esas imágenes pueden ser generadas y gestionadas en redes, por unas comunidades más extensas, eso nos da un ápice de optimismo. Si antes las imágenes eran exclusivas de unos reductos muy limitados, hoy nos convertimos en lo que yo llamo homo photograhicus. Formar parte de esa nueva especie implica tener la capacidad de producir 
tu propia imagen del mundo, no sólo de ti mismo, no solo cuidar tu apariencia o hacer tus selfies como reguladores de emociones o como interconectores de relaciones humanas. Son formas de ver el mundo y formatearlo, de generar un modelo con el que tú puedas interactuar.

MAR. En ese sentido, la postfotografía ¿no nos brinda otra posibilidad fantástica, que es la de producir esa visión propia del mundo no sólo a través de las imágenes que gestamos sino a poder apropiarnos o adoptar, usando tu lenguaje, la gran cantidad de imágenes ajenas que circulan? Me gusta mucho esa posibilidad que otorga de Certeau (1990, p. xxxviii) a los subalternos de "construir frases propias con un vocabulario y una sintaxis ajenos", algo parecido puede aplicarse a las imágenes. Volvemos al détournement [...] ¿No pueden esas imágenes ajenas, incluso provenientes de miradas "mecanizadas" como las de las cámaras de seguridad, dar formas visibles a otros mundos que han estado ocultos hasta ahora? Últimamente, en el seno de una investigación con una compañera especialista en migraciones y seguridad, me estoy interesando precisamente por las cámaras de video vigilancia y cómo sus imágenes, destinadas a controlar, pueden servir para visibilizar unas experiencias que hasta hoy eran invisibles... me gusta mucho pensar que toda imagen puede subvertirse, resistir a los fines que ha sido creada y mostrar otros visibles. Hay algo muy optimista en todo esto.

JF. Sí. Hace dos años comisarié una exposición que se titulaba "Un mundo paralelo"10 que se ocupaba de la utilización de Google Street View por diferentes artistas como sistema para 10 La exposición se celebró en 2019 en Arts Santa Mònica con la obra de 12 artistas.

Visto en: https://artssantamonica.gencat.cat/en/detall/Un-mon-parallel-00003 
proporcionar imaginarios paralelos al paisaje y a lo urbano. Dentro de las actividades complementarias a esta exposición un equipo de profesores del $\mathrm{IEFC}^{11}$ realizó una experiencia muy potente, muy emotiva, que fue pedir a una serie de emigrantes que habían entrado en España de forma ilegal, que a través de Google Street View (GSV) recuperasen sus itinerarios ${ }^{12}$. Todos de alguna forma intentaban reandar los pasos que habían dado hasta llegar a Barcelona a partir de las imágenes registradas por Google Street View. A menudo se trataba de vivencias profundamente dolorosas, gente que había perdido la familia en el recorrido, que las habían pasado canutas, que había sufrido lo indecible, se trataba de usar un instrumento tan cotidiano como es hoy para nosotros la herramienta del GSV para hacer una reconstrucción de ese viacrucis migratorio.

11 Institut d'Estudis Fotogràfics de Catalunya

$12 \mathrm{La}$ experiencia se llamó "RECONSTRUCCIÓ. 60.989 km. 18 vides, 18 identitats, 18 històries de joves migrants"Verse en: https://artssantamonica. gencat.cat/en/detall/RECONSTRUCCIO.-60.989-km 
Figura 4 - Imágenes de la exposición RECONSTRUCCIÓ. 60.989 $\mathrm{km}$. 18 vides, 18 identitats, 18 històries de joves migrants ${ }^{13} \mathrm{y}$ Joan Fontcuberta

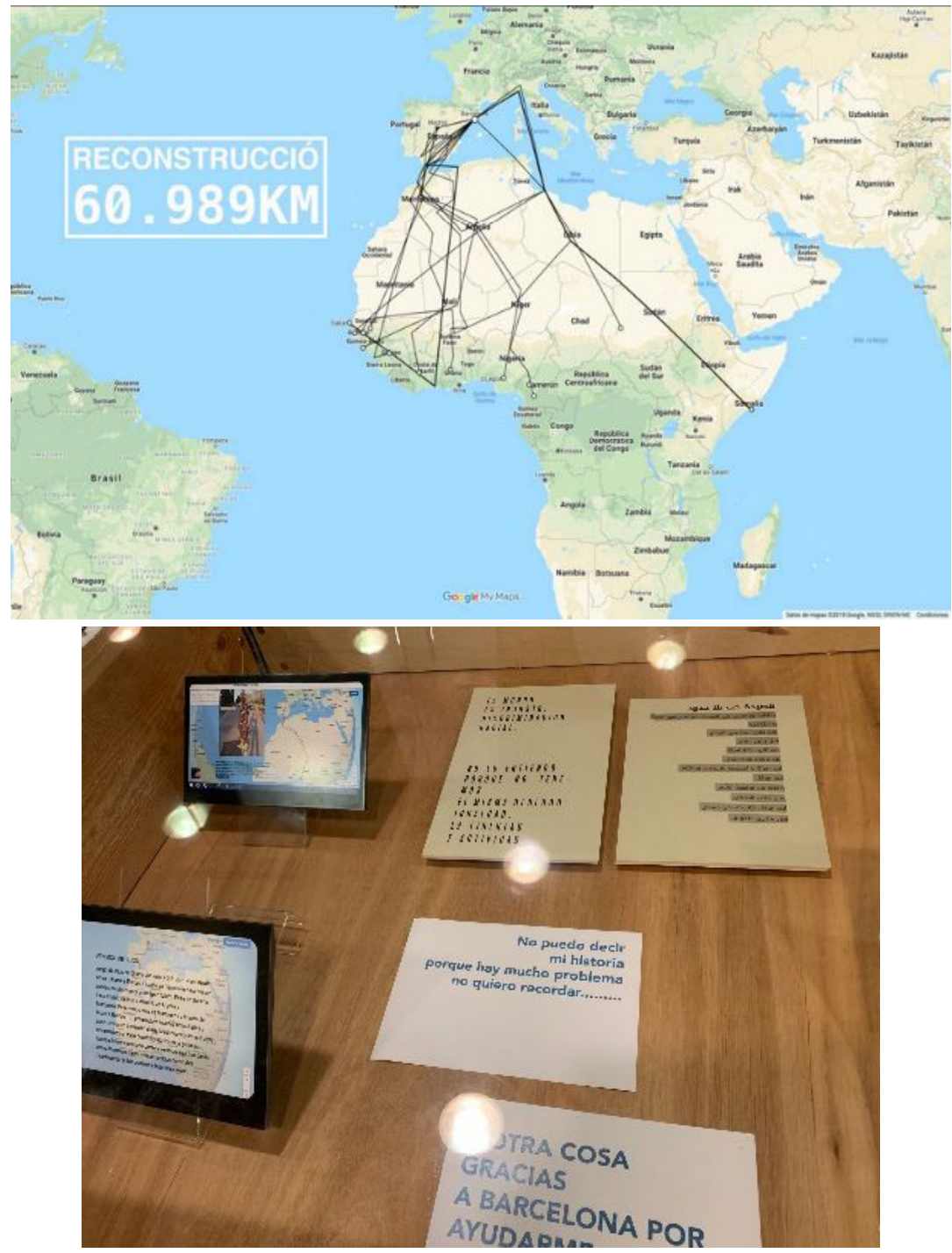

Fuente: cortesía del autor.

MAR. Para terminar, quisiera retomar la idea que has introducido de la existencia de imágenes desquiciadas, furiosas, resistentes incluso a su propio autor. Porque, todo esto que hemos descrito como posibilidades de crear comunidad, de formatear nuevos mundos, etc. ¿no tiene un trasunto en imágenes capaces de regresar, de volver incluso cuando no son convocadas? Por ejemplo, algunos 13 Visto en: https://artssantamonica.gencat.cat/en/detall/RECONSTRUCCIO.$60.989-\mathrm{km}$ 
270 Imágenes desquiciadas. Una conversación sobre (post)fotografía, tiempo y memoria con...

teóricos describen las dificultades de personas para completar los duelos de sus gentes cuando sus redes sociales siguen activas tras sus muertes y cuya imagen parece poder volver, espectralmente, sin ser llamada.

JF. En el fondo eso nos hace repensar qué significa ser humanos, en qué consiste la condición humana, qué nos diferencia de los robots pensantes, de las inteligencias artificiales. Hoy en día cualquiera de nosotros va dejando unas huellas, unos registros, que, en su conjunto, determinan una psicología, unos sentimientos, una cultura, una memoria, por lo tanto no es descabellado pensar que recopilando todos esos datos se podría programar un cuerpo, como el nuestro, y seguir siendo nosotros; seguir teniendo la conciencia que nos hace individuales. Es un argumento de ciencia ficción, hay muchas películas, y algún episodio de la serie Black Mirror, por ejemplo, que lo han desarrollado magistralmente. Como modelo de posibilidad yo lo veo claro, a lo mejor nuestra conciencia no es más que un disco duro potentísimo con una complejísima abundancia de datos, datos que pueden ser transferidos de un "contenedor-cuerpo A" a un "contenedor-cuerpo B", o directamente a una máquina. Desde la especulación de lo posible, ¿por qué no? Como hipótesis funciona. Siempre me ha fascinado tanto como me aterroriza lo que dijo un premio Nobel de Física: todo aquello que es pensable llegará a ser posible, simplemente hay que darle tiempo para que suceda. Es una contingencia remota, una serendipia, algo absolutamente improbable, pero, aunque haya una sola opción entre trillones, llegará un momento en que pase. 


\section{Coda. A modo de conclusión}

"El tema del azar me está apasionando mucho últimamente" añadiría Joan, y esta conversación derivaría hacia historias imposibles, como la de un hombre canadiense que, cosas del azar, tras ser atravesado por un rayo en varias ocasiones, terminó suicidándose por una pena de amor. Pero el azar-como ha mostrado continuamente el trabajo de Fontcuberta- no es sólo una extraordinaria fuente de historias fantásticas, sino también un instrumento heurístico inestimable.

Estar siempre abierto a la sorpresa y enfrentarse a lo real, a lo sensible, sin partir de ideas previas permite interrogar, como hemos tratado de hacer a lo largo de esta conversación, los modos en que, en torno a las imágenes y sus usos se articulan lo simbólico y lo afectivo; y permite interrogar, también, el actual régimen de lo visible para, a partir del mismo, cuestionar nuestra época a partir de las relaciones que establecemos con el tiempo, con el presente y el futuro, con nuestras propias experiencias, la memoria y la propia condición humana. Pero, por último, mirar desde el extrañamiento a las imágenes nos permite también verlas vivir sus vidas, ajenas al tiempo y a quienes las crearon, fuera de control, de quicio, desquiciadas.

\section{Referencias}

BENJAMIN, Walter. Obra de los pasajes. Madrid: Abada, 2013. (Obras, Libro v, v. 1). 
272 Imágenes desquiciadas. Una conversación sobre (post)fotografía, tiempo y memoria con...

CERTEAU, Michel de. L'invention du quotidien, I. Arts de faire. París: Gallimard, 1990.

CORONAVIRUS en Italia: como no pueden ir a la iglesia, un sacerdote le da misa a las selfies de sus feligreses. Clarín, Ciudad Autónoma de Buenos Aires, 19 mar. 2020. Viste. versión en línea.

FONTCUBERTA, Joan. La furia de las imágenes. Notas sobre la postfotografía. Barcelona: Galaxia Gutenberg, 2016.

FONTCUBERTA, Joan. Mictlán. Un ensayo de hauntología fotográfica. Ciudad de México: Hydra, 2020.

FONTCUBERTA, Joan. Un món paral·lel. Barcelona: Generalitat de Catalunya, 2017. Catálogo de exposición.

FREUD, Sigmund. Consideraciones de actualidad sobre la guerra y la muerte (1915). En: FREUD, Sigmund. El malestar en la cultura. Madrid: Alianza Editorial, 1982.

FUKUYAMA, Francis. The end of history? The National Interest, Washington, D C, n. 16, p. 3-18, 1989.

HARTOG, François. Régimes d'historicité. Présentisme et expériences du temps. París: Seuil, 2003.

HIRSCH, Marianne. La generación de la posmemoria. Madrid: Carpe Noctem, 2015.

KOSELLECK, Reinhart. Futuro pasado. Para una semántica de los tiempos históricos. Barcelona: Paidós, 1993.

LACHANCE, Jocelyn. Photos d'ados. À l'ère du numérique.

Québec: Les Presses de 1'Université Laval, 2013.

PILORGET-REZZOUK, Chloé. Deuil en quarantaine, l'impossible 
adieu. Libération, Paris, França, n. 12071, p. 14-15, 28-29 mar. 2020 .

TOVAR, Luis Carlos. Jardín de mi padre. Barcelona: RM, 2020.

VIRILIO, Paul. El cibermundo, la política de lo peor. Madrid: Cátedra, 1997. 